\title{
Kenya-China Trade in Manufactured Goods: A Competitive or Complementary Relationship?
}

\author{
Nancy Muthoni Githaiga ${ }^{1,2}$ \\ ${ }^{1}$ Central China Normal University, Wuhan, China \\ ${ }^{2}$ Murang'a University of Technology, Murang'a, Kenya \\ Email: gnancym@gmail.com
}

How to cite this paper: Githaiga, N. M. (2021). Kenya-China Trade in Manufactured Goods: A Competitive or Complementary Relationship? Open Journal of Social Sciences, 9, 96-117.

https://doi.org/10.4236/jss.2021.93007

Received: November 26, 2020

Accepted: March 9, 2021

Published: March 12, 2021

Copyright ( 2021 by author(s) and Scientific Research Publishing Inc. This work is licensed under the Creative Commons Attribution International License (CC BY 4.0).

http://creativecommons.org/licenses/by/4.0/ (c) (i) Open Access

\begin{abstract}
Trade between Kenya and China has increased in recent years, with a significant increase in imports from China. This study's objectives were to examine the nature of trade between Kenya and China in manufactured goods, analyze the Revealed Comparative Advantage (R.C.A.) and make recommendations for improving trade. This study was based on the Comparative Advantage Theory and used data from the United Nations Commodity Trade Statistics Database (U.N. Comtrade) from 1984 to 2015, as this period had complete data. The results suggest that the nature of trade in manufactured goods between Kenya and China is characterized by high imports from China and very low exports from Kenya-a large proportion of Kenya's manufactured exports end up in countries with which it has a clear trade framework. Moreover, Kenya lacks a comparative advantage for manufactured goods, while China has a high comparative advantage; therefore, Chinese exports complement Kenya's import needs. The research identified the lack of a comprehensive trade policy and strict rules of origin as serious challenges to trade between Kenya and China. In addition, Kenya's trade orientation in the manufacturing sector has been reduced by inadequate investment, limited value addition, and high labor costs. Resolving these obstacles is vital to overcoming trade imbalance and boosting Kenya's competitiveness, as the potential for future growth in trade in manufactured goods from Kenya to China is weak, based on existing economic specialization. Kenya should focus on a comprehensive trade policy with China, support more FDI in manufacturing, innovation, and technology, improve labor productivity and infrastructure, enhance its global value chains, and create new comparative advantages among others. This will improve the competitiveness of its products and increase trade orientation on the Chinese market and globally. The study concludes that Kenya-China trade in manufactured goods is complementary. This conclusion can only be applied in genera since the study used aggregate data. The findings confirm the Compara-
\end{abstract}


tive Advantage theory that countries export what they have in abundance and import goods that they cannot produce effectively.

\section{Keywords}

Kenya-China Trade, Manufactured Goods, Revealed Comparative Advantage, Nature of Trade, Competition

\section{Introduction}

The pattern of world trade is changing, with traditional exporters of primary products gradually moving to the global trading center due to their shift to the production of manufactured goods. This is due to the growing changes in Asian countries, particularly India and China, and the decline in demand for raw materials due to the shift from industrial production to service delivery in northern countries. China, the largest developing country, has more than $90 \%$ of its exports of manufactured goods, making it a force to be reckoned with globally (Suresh \& Neeraj, 2014; UNECA, 2015). The share of developing countries in world trade increased from around 20\% in 1970 to around $42 \%$ in 2010, compared to a decrease from $76 \%$ to $54 \%$ in the share of developed countries in the same period. However, Asia's developing countries accounted for approximately $33 \%$ of total world trade in 2010 , up from $8.42 \%$ in 1970 . The respective figures for African developing countries are 4.98 per cent and 3.31 per cent, indicating a decline in world trade in developing African countries (UNCTAD, 2008).

While Kenya ranks among the leaders of the post-colonial effort to industrialize in Africa, its industrial development has not been equal to its recent growth or national objectives. Manufacturing, which is a key driver of overall growth in Kenya, has declined significantly over the last three decades. As a share of G.D.P., manufacturing output has stagnated compared to the agriculture and services sectors, making the service sector the largest contributor to G.D.P. As of 2015, Kenya's current account deficit remained at $9.8 \%$ of G.D.P. in the midst of falling oil prices. In addition, imports of capital goods and equipment increased by more than $25 \%$ as exports decreased alarmingly. Kenya's net exports steadily decreased by 14 per cent annually between 2000 and 2004 and reached a low of US $\$ 12.2$ billion in 2014 (GOK, 2015). This imbalance of trade calls for serious efforts in boosting manufacturing.

Over the years, China has become Kenya's primary trading partner due to improved bilateral relations between the two partners over the last 15 years (Omolo, Jairo, \& Wanja, 2016). In 2015, China became the first country to export KSh300 billion to Kenya, underpinning its growing economic importance in the country as reported in the Daily Nation (April 5/2016). Imports from China have increased enormously over the years, from Ksh 167.2 billion in 2012 to Ksh 390 billion in 2017, accounting for 22.6\% of Kenya's imports in 2017, while Kenya's exports to China increased to Ksh 10 billion in 2016 from Ksh 5.3 
billion in 2012 but decreased slightly to Ksh 9.9 billion in 2017 (Odhiambo \& Malot, 2018). China's high import bill has caused a trade imbalance between the two countries, which is heavily skewed in favor of China. According to the UN Comtrade Database (2015), Kenya mainly imports manufactured products from China, while China imports a small (1\%) share of Kenyan products. Products exported by Kenya to China have limited value addition, making them uncompetitive in terms of prices. China is a leading developing country and is more likely to increase its exports in different sectors, while Kenya is heavily dependent on commodity and agricultural exports as a lower-middle-income country. As a result, Kenya would be expected to export commodities to China, and China would export a wide range of manufactured commodities (World Bank Group, 2015). However, Kenya exports comparatively diverse products, ranging from metals, plastics, vegetable, textile, and leather rawhide skins, which are opening up to meet the demand for leather on the Chinese and European Union markets (Omolo, Jairo, \& Wanja, 2016).

The growth of the manufacturing sector in Kenya has decreased as the trade between the two partners has increased, for instance, it was only 3.4\% in 2014, down from 5.6\% in 2013 (Chen, Geiger, \& Fu, 2015). Kenya's exports are reported to have been performing terribly due to the weak manufacturing sector. According to the World Bank Group (2015), manufacturing has remained at only $10 \%$ of G.D.P. for more than 10 years. To address these shortfalls in the manufacturing sector, Kenya's Vision 2030 aims at a robust, diversified and competitive manufacturing sector and focuses on the sector as a driver of exports and overall growth. Experience in countries that have achieved sustained, rapid growth since the 1960s shows that such growth has typically been accompanied by a sharp increase in the share of exports in the G.D.P. and, in most cases, in the share of manufacturing in both exports and the G.D.P. Manufacturing has the potential to play a crucial role in putting Kenya on a sustainable growth path through its direct contribution to creating quality employment, through its strong linkages with other parts of the economy, by raising capital accumulation, by smoothing volatility in the economy, and by facilitating global integration and knowledge spillovers which are critical to the process of structural transformation.

Manufacturing is only one of the key sectors to achieving the Vision 2030 target, with services, particularly tourism, transport, construction, and I.C.T., likely to be needed for G.D.P. and export growth. However, given that Kenya produces and trades a few intermediate goods, it is believed that Chinese imports could weaken the manufacturing sector. Without a strategic improvement in the manufacturing sector, the outlook for economic growth is limited. Kenya will need to promote more FDI in manufacturing, improve the efficiency of labor and general infrastructure, reduce transport costs and ease trade regulatory procedures to increase exports and the share of the manufacturing sector in the G.D.P (Farole, 2011).

It is against increased trade in manufactured goods that this research was car- 
ried out with three main objectives: to examine the nature of trade in manufactured goods between Kenya and China, to analyze the Revealed Comparative Advantage (R.C.A.), and to make recommendations for improving trade. This study's importance lies in the role played by the manufacturing sector as a dynamic driver of growth and development, as China's experience shows. Understanding the nature and competitiveness of Kenya's manufactured goods in China is a crucial step towards enhancing the critical role of manufacturing in Kenya's development process. Research on trade in manufactured goods between Kenya and China has important implications for enhancing Kenya's manufacturing sector and deepening Kenya-China trade cooperation and integration through enhanced participation of Kenyan manufacturers in the Chinese market; the adoption of innovative ways to trade from the Chinese market to Kenya, and the development of business relationships based on reliable approaches.

This research contributes to the literature by focusing on the Revealed Comparative Advantage of Trade in Manufacturing Goods and using complete data from 1984 to 2015. The researcher has not extended this analysis to more recent years due to data unavailability and inconsistencies. The study was limited because it used aggregate data (Standard International Trade Classification-Class One Goods) to limit the range of issues that could be addressed concerning specific industries/firms. As a result, the conclusion of this research is derived from aggregate trade data. Although this study concluded that trade between China and Kenya is mainly complementary, imports from China may have brought competition to local producers for specific products or groups of products. Thus, a more detailed analysis of trade at a product and firm-level would be required to further explore complementarity and/or competition.

\section{Literature and Theoretical Review}

\subsection{The Nature of Kenya-China Bilateral Trade}

Previous research on bilateral trade between Kenya and China has yielded mixed results, with positive, negative and neutral findings from various studies. As Onjala (2008) points out, trade policy and framework play an important role in bilateral trade between countries. The first trade agreement between Kenya and China was signed in 1964 and was revised in 1978. Kenyan imports began to increase in the late 1990s, albeit with minimal exports from Kenya to China, with a skewed trade balance favoring China (Ademola, Bankole, \& Adewuyi, 2016; Onjala, 2008). The increase in imports from China and other countries was due to the liberalization of the exchange rate in Kenya and the lowering of external tariffs, which led to lower real import prices. Second, China's industrialization has given rise to cheap competitive goods attracting Kenyan markets (Chege, 2008). Various factors have influenced the growth of trade between China and Kenya, including external environmental factors such as the political environment, the legal environment and the economic, socio-cultural and technological environment (Nguku, 2013; Siringi, 2018). 
China's emergence as a force to be reckoned with in world trade, and more so in Kenya, could be attributed to three main factors; China's high economic growth rate over the last two decades, with the economy growing by an average of $10 \%$ annually and an increase in G.D.P.; China's vast economy, combined with its vast population of about 1.3 billion people, offers a substantial domestic base to stimulate growth (Githaiga, Burimaso, Bing, \& Ahmed, 2019; Li \& Li, 2020). Indeed, China's share of world exports has increased significantly over the last three decades. Industrialization and economic growth have led to a significant increase in demand for fuel, and hard commodity prices have risen globally since 2000 (Titiloye Ademola, Bankole, \& Mefalopulos, 2009). The role of the Government cannot be downplayed in the increased presence of Chinese manufactured products and companies in Kenya. The Government of China provides capital to Chinese companies to invest in the Kenyan market, increasing their competitiveness (Patroba, 2012). For example, China's state-owned Exim Bank has provided massive support to Chinese firms in expanding their presence in Africa (Foster, Butterfield, Chen, \& Pushak, 2008).

Studies show that China enjoys a comparative advantage in low-priced manufactured goods, as its manufacturing and infrastructure sectors are highly integrated into global value chains. As a result, China is a major source of imports from Kenya, in particular rubber products, machinery, equipment and electronics. Kenya, on the other hand, lacks a comparative advantage in manufactured goods due to the weak rule of law, poor infrastructure, and barriers to production. As a result, this hinders growth in the manufacturing sector, making it difficult for local producers to compete with Chinese manufactured goods (Sanghi \& Johnson, 2016; Warui, 2010). Kenya's main imports from China include machinery, equipment, and parts for specialized industries to China and export unfinished products (Onjala, 2010). Previous research also shows that China is not a substantial export market for Kenyan products and exports, mainly unfinished raw goods and metals and an insignificant percentage of manufactured goods. This is partly due to a lack of natural resources, such as oil, like a few other African countries. As a result, Kenya has not achieved much by taking advantage of China's recent commodity boom to increase its exports. Besides, Kenya lacks a comparative advantage over other Chinese imports (apart from natural resources) such as soybeans, wheat, and corn (Sanghi \& Johnson, 2016). Some of the primary commodities that Kenya exports to China could be critical inputs to the Kenyan manufacturing sector, which is still underdeveloped (Onjala, 2010).

Although both countries have developed policies that have seen an increase in foreign direct investment (FDI), trade remains highly imbalanced in favor of China. The trade partnership between them is of high value to Kenya in terms of job creation, economic development, and the promotion of social relations

\subsection{Gains and Losses of Trade in Manufactured Goods}

Various studies have mixed findings on trade between Kenya and China. Optimists such as Onjala (2008) argue that, overall, the export trends and patterns 
of Kenya's major export products to China suggest that trade relations have benefited Kenya, in particular by supporting various economic activities through back-to-back links such as employment and general development, as well as providing an opportunity for Kenya to participate in the global market of chains. Moreover, China sees Kenya as a gateway to East Africa in terms of trade and economic partnership, leading to these gains. The complementarity and gains of the trade partnership are evident in the growth of Kenyan exports to China and Kenya, consumer welfare gains with alternatives to cheaper manufactured goods, and access to Chinese markets for Kenyan traders (Onjala, 2010; Warui, 2010). Cheaper goods mean richer consumers with more disposable and real income (Sanghi \& Johnson, 2016). Increased imports of manufactured goods provide producers with affordable and inexpensive inputs and intermediate goods that they could use in manufacturing. Consequently, Chinese imports do not, in essence, displace local products, since they may also displace imports from other countries to Kenya, reduce the cost of imports in general through cheap manufactured goods, increase labor output and productivity in certain sectors, and boost employment in the service industry (Sanghi \& Johnson, 2016). In addition, it is argued that China's cheap exports to Africa are tailored to the local market and intended to respond to Africa's demand for cheap and affordable commodities (Guerrero, Manji, \& Manji, 2008). Therefore, exporting cheap goods to Kenya is not an exploitation, as long as the goods are not counterfeit or compromised on quality (Møller, 2012).

The trade model between Kenya and China has also been argued to offer a different and alternative development model where China's relationship with African countries aims to achieve tangible and progressive development outcomes with favorable conditions for both parties. To this end, Kenya's trade with China is claimed to have enhanced technology and skills transfer and improved domestic enterprises; the magnitude of this likelihood has been generated by leveraging some domestic companies, such as Kariobangi Cottage Industries, to manufacture similar products (Onjala, 2010, 2017).

Other studies suggest potential losers in the trade partnership between the two countries, which could negatively affect the nature of trade. Warui (2010) notes that the fast-growing deficit in Kenya and trade patterns in China have directly and indirectly affected their trade relations. For example, China poses competition threats to local manufacturers in both domestic and foreign markets, which have directly and indirectly negatively affected local production (Warui, 2010), i.e. cheap Chinese foot wares and clothing, and second-hand clothing in general, are more dominant than home-grown products. This has affected local producers who are unable to compete with these cheap manufactured goods. As a result, Kenya's manufacturing growth has decreased every year as consumers prefer Chinese goods, which are about $10 \%$ cheaper, even leading to some companies' closure (Patroba, 2012). In addition, the import of certain goods that can be produced locally, such as onions, clothing, fish, cement, among others, creates direct competition for local industries and has exacerbated trade imbalances (Od- 
hiambo \& Malot, 2018). Alongside increased imports from China, Kenya's minimal production and trade in intermediate goods could lead to de-industrialization ${ }^{1}$ (Chen et al., 2015).

Some studies argue that there has been a significant loss of Kenyan exports internationally due to duplication of local products by Chinese manufacturers and trading them at a lower price to Kenya's trading partners, thus driving local producers out of the market. These cheap manufactured goods have made it impossible for Kenyan producers to compete with Chinese producers, particularly in the manufacturing and textile sectors (Abdirahman, 2020; Onjala, 2008). For example, with the launch of the African Growth and Opportunity Act (AGOA) and the Multi-Fiber Agreement (M.F.A.), Kenya exported more than $90 \%$ of its textile exports to the U.S.; exports increased by $29 \%$ from US $\$ 78$ million to US $\$ 306$ million. However, Kenya's share of textile exports to the USA decreased partly due to China's increased market share in the US between 2004 and 2006. Competition from Chinese products led to a reduction in Kenya's exports following the removal of the M.F.A. and threatened Kenya's gains on the US market (Kaplinsky, McCormick, \& Morris, 2010). Jobs have also been lost in Kenya as a result of the closure of some local factories. Kenya is not the only country that has been affected. In Lesotho, a rough estimate of 10 factories in the textile sector ended their operations in 2005, leading to job losses for approximately 10,000 workers. Similarly, in South Africa, textile exports decreased from US $\$ 26$ million to US $\$ 12$ million in 2005 (Leseure, Hurreeram, \& Bennett, 2009). There has also been a loss of regional trade for Kenyan manufactured goods due to increased Chinese imports. Kenya's share of trade in the East African region has recently declined due to the displacement of some of Kenya's exports by imports from China to these countries, more so in second-hand clothing; cheap foot wears among other products (Adem, 2016). This has led to a decline in local firms that export to E.A.C., either reducing their production or shutting down their operations. As a result, Kenya's comparative advantage has been reduced, among other social costs.

Besides, Chinese exports to Kenya are reported to have quality issues with reports of sub-standard counterfeits. A report by the Kenya Association of Manufacturers (KAM, 2007) indicates that China is the primary source of low quality and counterfeit goods in Kenya, resulting in a high annual loss. Manufacturers feel the impact of counterfeit products through erosion of brands, loss of sales and market share, closure of factories, and unfair competition. Counterfeits cost the government approximately $\$ 84$ - 490 million in lost taxes each year, and the tracking of counterfeit activities absorbs valuable resources and discourages innovation in new products, as companies fear unfair competition (Patroba, 2012). Kenya, therefore, needs to lay down strict quality control regulations for its imports.

The above literature gives an overall picture of mixed findings where trade losses and gains have occurred. Kenya has gained a significant degree, particu${ }^{1}$ A process where a country's industrial activity is reduced which is a typical indicator of a shift to a service driven economy. 
larly in job creation, skills and technology spillover, cheap and alternative consumer imports and infrastructural development. However, policymakers need to take advantage of China's potential benefits to the Kenyan economy and work out measures to improve the trade balance between the two countries. Obviously, China is a huge prospective market for Kenyan goods, although China is better positioned to increase its market in Kenya due to its current level of expertise, skills, and specialization. The recent discovery of oil in Kenya, where China is very interested, is one of Kenya's potential market expansion areas. There is also a need to create a more robust policy framework for Kenya-China trade relations and create channels for future balanced interdependence between the two partners, improving their economic relationship. Kenya also needs to take the necessary measures to exploit the market in China and broaden future financing of economic growth by ensuring that inferior products are not dumped on the Kenyan market. Kenya needs to boost its manufacturing sector by enhancing producer skills and specialization in areas where they have a comparative advantage to compete with China's low-cost manufacturing sector.

\subsection{Comparative Advantage Theory}

This study was based on the comparative advantage theory, also known as Heckscher-Ohlin, developed by two Swedish economists, Eli Heckscher and Bertil Ohlin. The theory emphasizes the relationship between the proportions in which different factors of production are attainable and accessible in different countries and the proportions in which they are used in the production of different goods, also known as factor-proportion theory. This theory explains that the comparative advantage is influenced by the interaction between national resources (relative abundance of production factors) and production technology (which affects the relative intensity with which various production factors are utilized in the production of various goods). The Comparative Advantage Theory States that "countries will export goods that their labor produces efficiently and imports goods that their labor produces relatively inefficiently" (Krugman \& Obstfeld, 2009). For a country to have a comparative advantage, it must produce a particular product at a lower opportunity cost than the other country. A nation exports goods produced from its relatively abundant and cheap factors or resources and imports commodities produced from relatively scarce factors or resources. This means that countries that are relatively labor-intensive export goods that are relatively labor-intensive and import relatively capital-intensive goods.

Variations in technology and infrastructure are very significant for the economic development of countries. Considerable variations in technological advancement and infrastructural development between China and Kenya defy the basic assumptions of the neoclassical trade theory of mobility of domestic factors at no cost and similar technology. Comparative advantage is created and not endowed in the modern world, and this process of creation is driven by technology determined by human actions and policies (Palley, 2008). Relative labor, capital and resource endowments significantly define trade patterns between 
Africa and China and the specific patterns of trade between individual African countries and China. The result is generally balanced trade between Africa as a whole and China. However, significant differences are realized when China is compared with individual African countries for the balance of trade favors those with natural resources, while oil exporters generally experience a trade imbalance with China.

\section{Research Methodology}

This research used a mixed approach research design of both qualitative and quantitative methods. Qualitative analysis was used to review the relevant literature on this subject, while quantitative analysis analyzed data on the nature of trade in manufactured goods and the Revealed Comparative Advantage (R.C.A) of trade using R.C.A. Indexes at the Standard International Trade Classification (SITC) level. The results were graphically presented.

The main source of primary data was the United Nations Commodity Trade Statistics Database (U.N. Comtrade), while secondary sources included World Bank Trade Statistics; Kenya National Bureau of Statistics; books; journals, as well as published and unpublished materials and relevant websites. The data collected covered the period 1980 to 2015. The researcher could not extend this analysis to more recent years due to complications on data; inaccuracies due to the deliberate omission of specific years is a source of error for data in the U.N. Comtrade database

The Revealed Comparative Advantage (R.C.A.) index was calculated to show the competitiveness or lack of-for manufactured goods. The R.C.A Index shows how the product in the exporting countries compares to the share of the product in global (world) trade. A high R.C.A. product is competitive and can be exported to low R.C.A. countries, resulting in complementarity. Revealed comparative advantage (R.C.A.) measures have often been employed to assess the country's export potential. The R.C.A. shows whether a country is in the process of spreading the products in which it has a trade potential, as opposed to situations in which the number of products that can be competitively exported is fixed. It also shows important information on potential trade projections with new partners. Countries with the same R.C.A. profiles are not likely to have high bilateral trade intensities unless intra-industry trade is involved. This study adopted the R.C.A. calculation formula of the World Bank. The R.C.A. index of country " $i$ " for product $j$ is often measured by the product's share in the country's exports in relation to its share of world trade:

$$
\operatorname{RCA}_{i j}=\left(x_{i j} / X_{i t}\right) /\left(x_{w j} / X_{w t}\right)
$$

$X_{i j}$ and $X_{w j}$ are the country's exports of product $j$ and world exports of product $j$, while $X_{i t}$ and $X_{w t}$ are the country's total exports and total world exports. A value of less than one indicates that the country has a comparative disadvantage in the product. Likewise, if the index is more than one, it is believed that it pos- 
sesses a comparative advantage in the product.

These indices for Kenya and China were computed at the Standard International Trade Classification (SITC) digit one level. The World Bank definition of manufactured goods (adopted by this study) covers Sections 5 through 8 of the SITC, including chemicals and related products, manufactured products classified chiefly by material, machinery, transport equipment, and miscellaneous manufactured articles.

\section{Results}

\subsection{The Nature of Trade on Manufactured Goods between China and Kenya}

\section{China Is a Major Source of Kenya Imports}

Figure 1 shows Kenya's imports from China from 1984 to 2015. China's share of Kenya's imports has progressively increased from negligible amounts in the 80 s - 90s to high levels in the millennium years. In 1984, Kenya's imports from China accounted for only $3 \%$ of its total imports, but by the end of 2015 , China's imports had reached $26 \%$ of Kenya's total imports. Most of these imported goods belong to the class of manufactured goods, which could be explained by the recent increase in Kenya's infrastructure development. It is worth noting that despite the decline in Kenya's imports from the world between 2014 and 2015, imports from China continued to increase.

Kenya imports from China compared to India, Kenya's two top sources of imports

Figure 2 shows the trends in imports between China and India to Kenya, the top two import sources for Kenya. Kenya's import bill structure shows a declining trend in India's dominance as Kenya's import partner between 1984 and 2015, while China rose gradually. India was the leading source of Kenyan imports

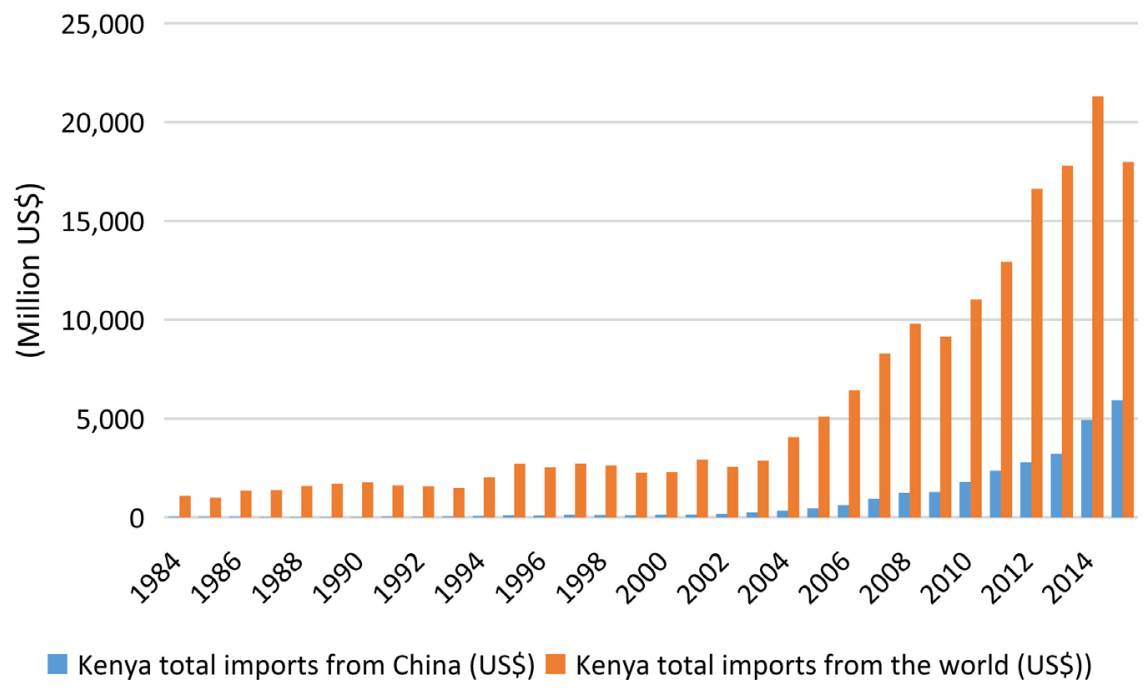

Figure 1. China is a significant source of Kenya's imports (1984-2015). Source: U.N. Comtrade Database 2015. 


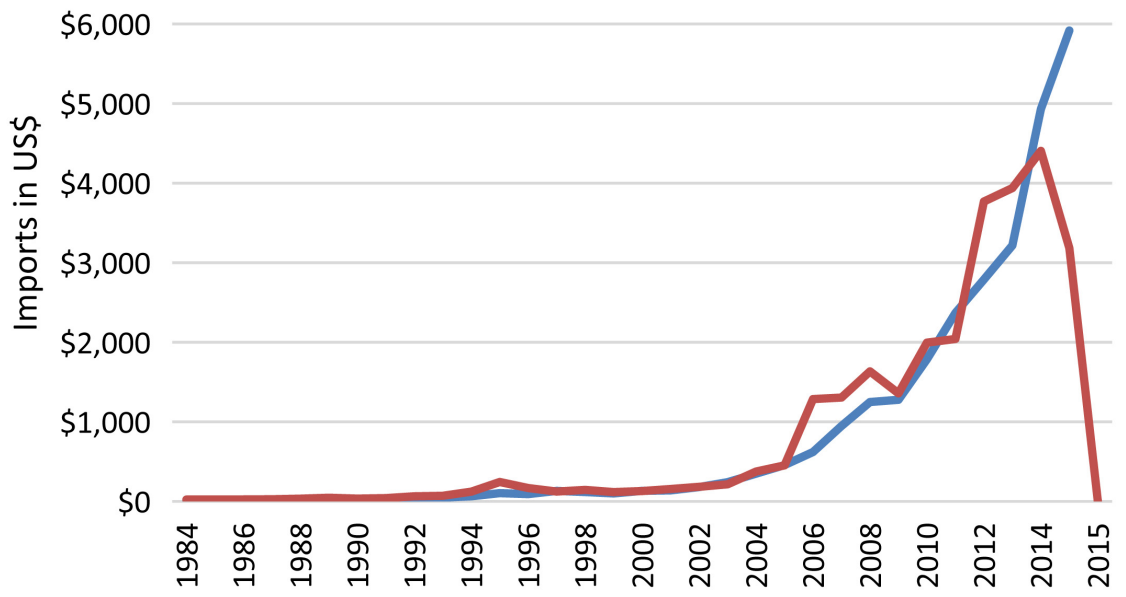

Kenya imports from China (US\$) — Kenya imports from India (US\$)

Figure 2. Kenya's imports from China and India. Source: U.N. Comtrade database 2015.

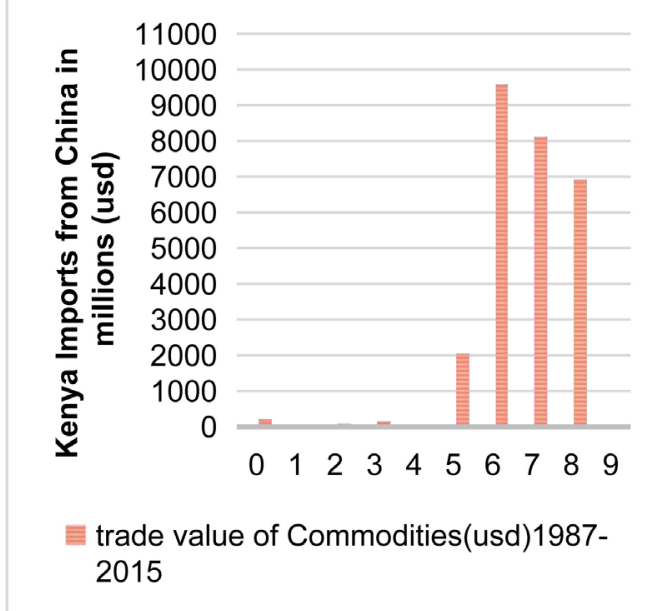

(a)

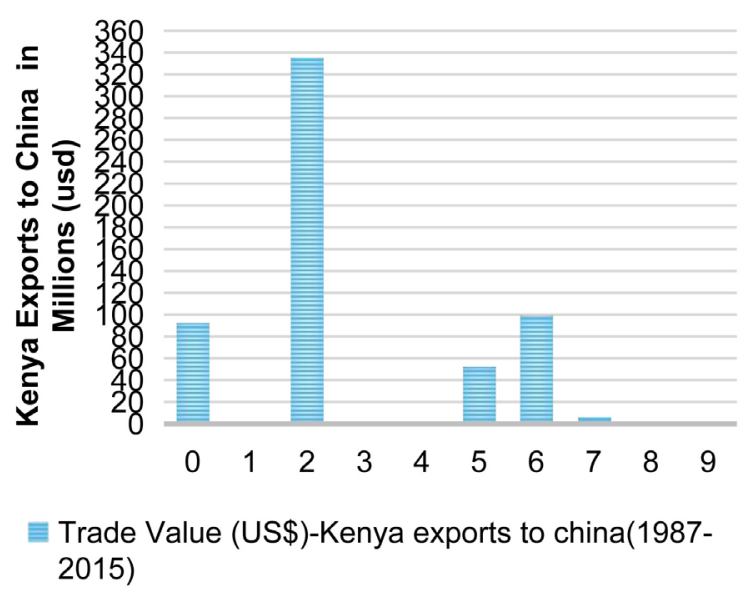

(b)

The numbers o to 9 represent the different trade commodities: 1-food and live animals; 2-beverages and tobacco; 3-crude materials, inedible except fuels; 4-mineral fuels, lubricants and related materials; 5-animal and vegetable oils and fats; 6-chemicals; 7-manufactured goods classified chiefly by material; 8-machinery and transport equipment; 9-miscellaneous manufactured articles; $10-$ commodity and transacts. Not class accord. To kind respectively.

Figure 3. Kenya's import of manufactured goods from China \& Kenya's export of manufactured goods to China. Source: U.N. Comtrade, 2015.

until 2014, when there was a significant shift, and China overtook it to become the leading source of Kenyan imports.

\section{Kenya mainly imports manufactured goods from China.}

Figure 3(a) shows that Kenya's top imports from China are mainly manufactured goods, just like most other Sub-Saharan Africa countries. The top four import categories from China include: manufactured goods classified chiefly by material made up $26 \%$, machinery and transport equipment $23 \%$, miscellaneous 


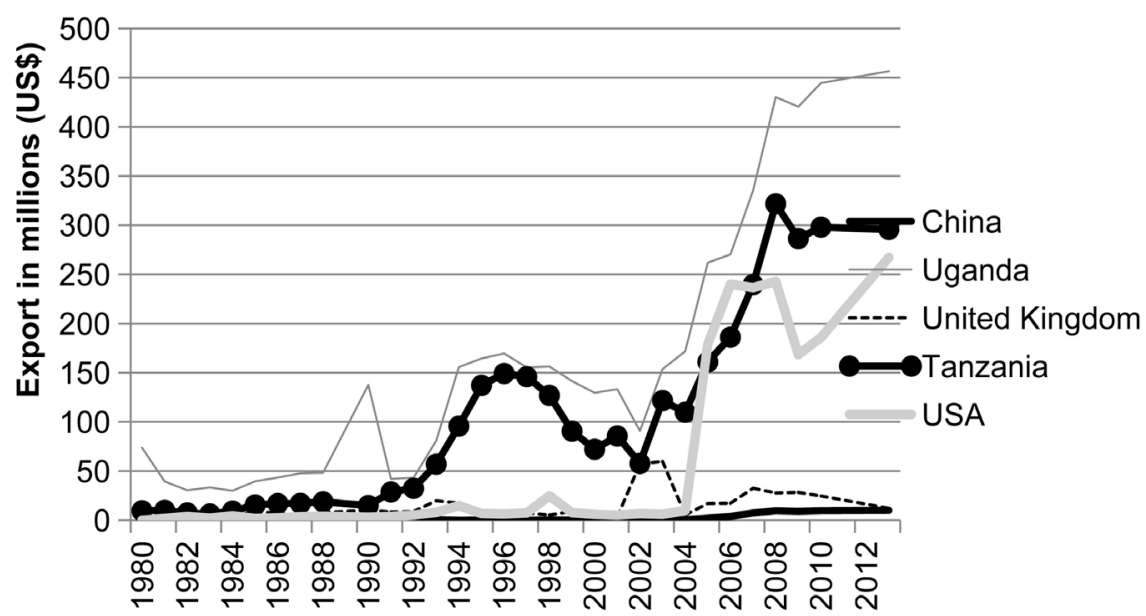

Figure 4. Kenya exports of manufactured goods to East Africa, USA, and UK compared to China. Source: U.N. Comtrade database 2015.

manufactured articles $20 \%$, and chemical and related products were $7 \%$ of total imports from China between 1987 and 2015. On the other hand, Figure 3(b) shows that Kenya's exports of manufactured goods make up a very small proportion of its total exports to China. Kenya mainly exports raw goods to China, and the composition and percentage of the goods produced are minimal. Beverages and tobacco account for the highest percentage of exports. The four main exports to China between1987-2015 are Crude materials, inedible, except fuels making up to $35 \%$, manufactured goods classified chiefly by material-14\%, Food and live animals making up to $12 \%$ and chemicals $8 \%$ of Kenya's total exports to China.

Kenya exports of manufactured goods to E.A.C., USA, UK in comparison with China.

Figure 4 shows that Kenya's exports of manufactured goods to China are the least of the five countries (4 regions) analyzed. However, it should be noted that there has been some growth in exports of manufactured goods to China, particularly from 2000 to 2013.

\subsection{Revealed Comparative Advantage (R.C.A.) of Manufactured Goods between Kenya and China}

\section{Revealed Comparative Advantage (R.C.A.) for Chemicals}

Figure 5(a) \& Figure 5(b) below shows that the R.C.A. for chemicals for both Kenya and China has been below unity apart from 2008 for Kenya. However, it is worth noting that Kenya has had a higher mean of R.C.A. than China in chemical products, although both are continually lacking a comparative advantage. This means that there is room for Kenya to improve the R.C.A. on chemicals and to trade more with China.

\section{Revealed Comparative Advantage of Manufactured Goods Classified}

\section{Chiefly by Material.}

Figure 6(a) shows that China's R.C.A. in manufactured goods classified chiefly by material was mostly above unity between 1984-2015. While Figure 6(b) shows 


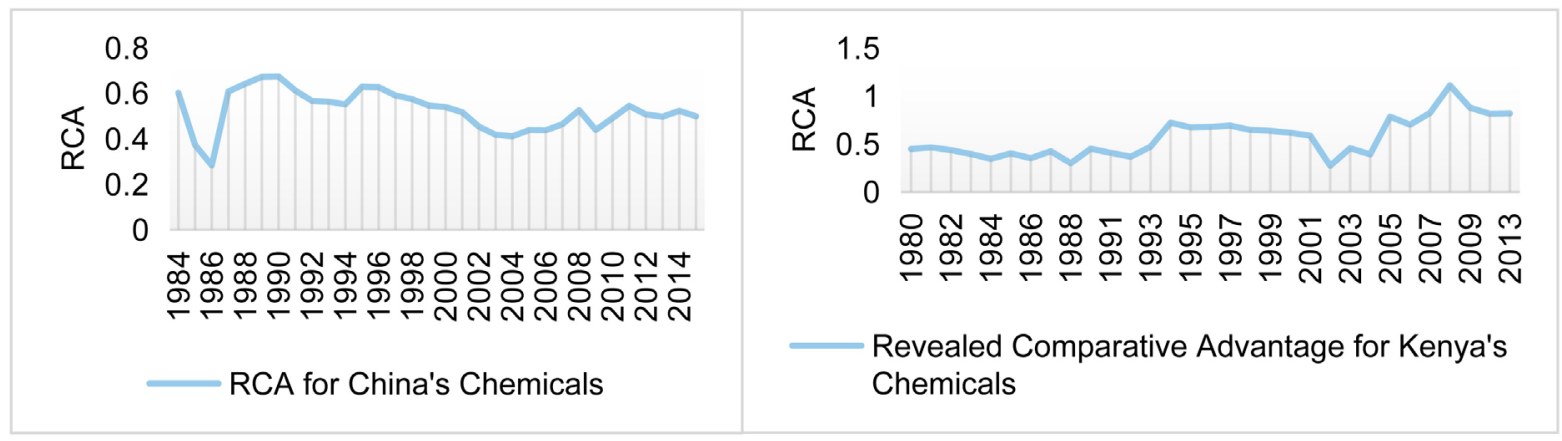

(a)

Figure 5. China and Kenya's R.C.A. for chemicals. Source: U.N. Comtrade database 2015.

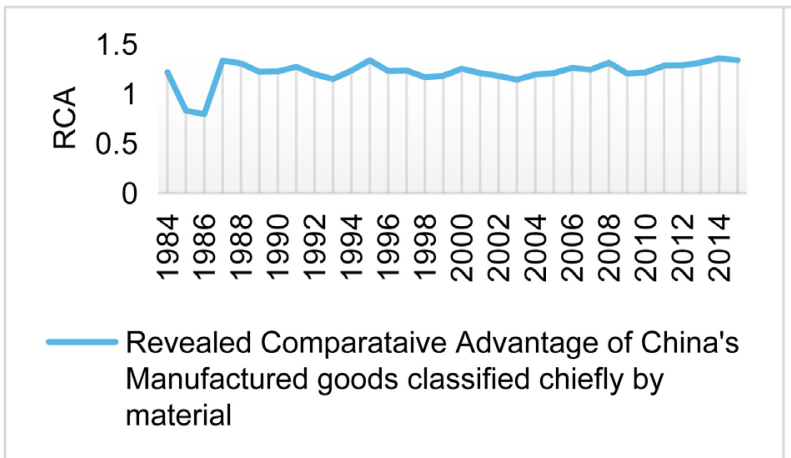

(a)

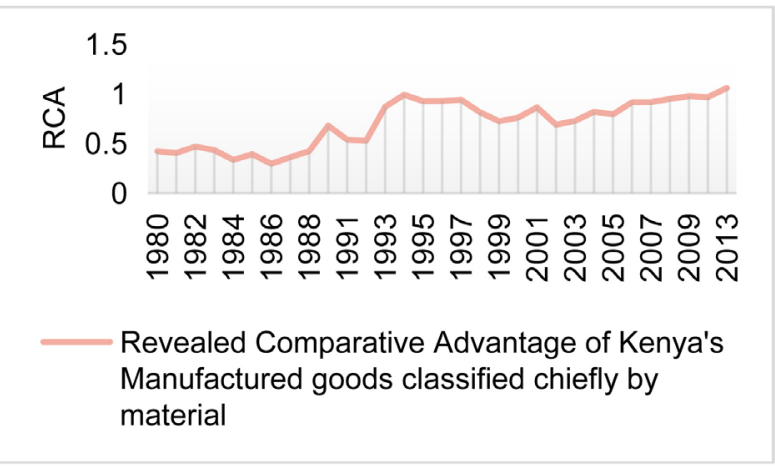

(b)

Figure 6. China \& Kenya's R.C.A. for manufactured goods classified chiefly by material. Source: U.N. Comtrade database 2015.

that Kenya's R.C.A. was mostly below unity between 1983-2015. Thus China enjoys a comparative advantage while Kenya has a comparative disadvantage in this class of goods.

\section{Revealed Comparative Advantage for Machinery and Equipment}

Figure 7(a) shows that China's R.C.A. for machinery and equipment has steadily increased. From 1984 to 2003, the R.C.A. was below unity, meaning a comparative disadvantage, but from 2004 to 2015, the R.C.A. took a new shape and rose above unity, marking a comparative advantage for this class of goods. On the other hand, Kenya's R.C.A. for Machinery and Equipment was continuously low and below unity from 1984-2015, as shown in Figure (7b). This means that Kenya has a comparative disadvantage in this type of goods.

Revealed Comparative Advantage for Miscellaneous Manufactured Goods Articles

Figure 8(a) shows that China had a mean R.C.A. of more than unity between 1984 and 2015, a comparative advantage for Miscellaneous Manufactured Goods Articles. On the other hand, Figure 8(b) shows that Kenya has had variations in the R.C.A. of Miscellaneous manufactured goods. Except for 1992, 2006 and 2007, the R.C.A. remained below unity for the rest of the years, which means a comparative disadvantage for Kenya in this class of goods. 


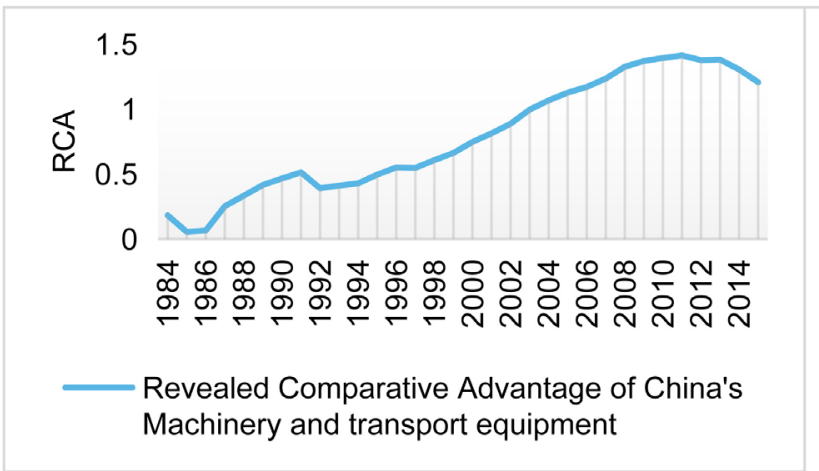

(a)

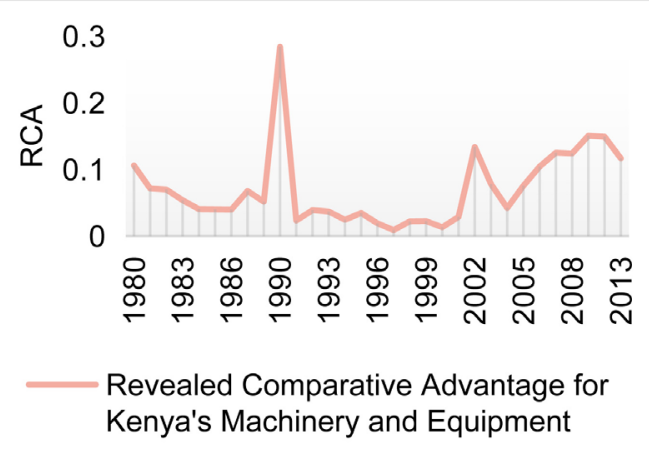

(b)

Figure 7. China and Kenya’s R.C.A. for Machinery and equipment. Source: U.N. Comtrade database 2015.

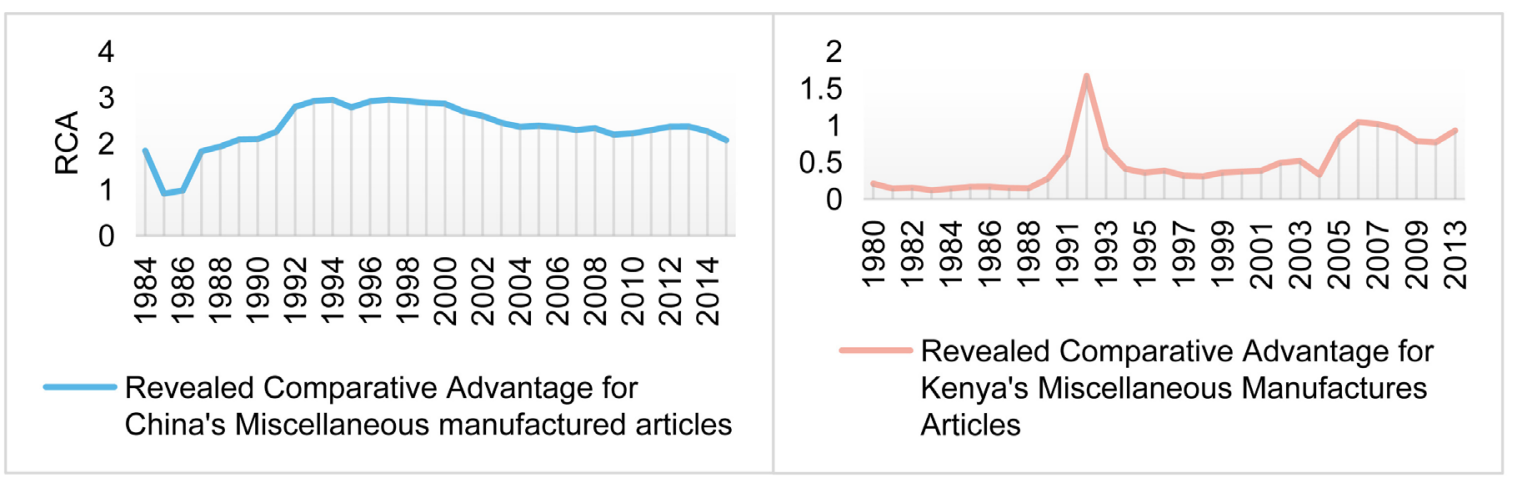

(a)

(b)

Figure 8. R.C.A. for China and Kenya's Miscellaneous Manufactured goods articles. Source: U.N. Comtrade database 2015 .

\section{Discussion of Results}

\subsection{The Nature of Trade on Manufactured Good between Kenya and China}

From the above results, it is clear that China is a major source of Kenya's imports, mainly of manufactured goods, while Kenya's exports to China are minimal and consist mainly of raw goods, with a very small percentage of manufactured goods. Several factors, including China's low production and labor costs, technological advancements, skilled labor, better infrastructure, and better positioning in the global production value chains, have made it possible for China to have a comparative advantage in producing competitive and cheap manufactured goods on its way to Kenya and other developing countries.

Various factors could explain the rapid increase in the import of industrial goods from China. First, increasingly large-scale infrastructure projects in Kenya (Githaiga, 2021). The Government of Kenya has increasingly continued to develop the infrastructure of the country. According to the Statistics Bureau (KNBS), the growth of the infrastructure sector increased to $13.6 \%$ in 2015 compared to $13.1 \%$ in 2014 . This was mainly attributed to the implementation of significant energy and transport infrastructure projects under the vision 2030 (Deloitte, 
2016). A significant number of such projects are carried out by Chinese companies, such as the Standard Gauge Railway connecting Mombasa and Nairobi by China Road and Corporation; the construction of Lamu Port Berths by China Communications Construction Company, Northern Corridor Integration projects, among others (Githaiga \& Bing, 2019). Second, Kenya's structural adjustment programs (SAPs) failed in the 1980s. SAPs were designed to strengthen competitiveness and reduce excess capacity in the industrial sector due to the Import Substitution Strategy (I.S.S.) of the 1970s. These included the virtual elimination of price controls and imports' liberalization by removing import and foreign exchange licensing and rationalized tariff regimes. These led to the liberalization of the domestic economy-for both output and input markets-and opened it up to the international competition. However, the industrial sector remained inward-looking, overly import-dependent, capital-intensive, and unable to absorb an adequate proportion of rapidly increasing labor force due to poor timing and lack of government commitment. The Government has done little to implement effective policies to promote exports (Chege, 2008; Gertz, 2008). Insufficient exchange-rate adjustments in the 1980s frustrated import liberalization while inefficient fiscal adjustments worked against investment. The result was a persistent bias against exports despite the announced shift from import substitution to an outward-looking export strategy (Chege, Ngui, \& Kimuyu, 2014). This resulted in increased imports from China and the world to Kenya from the 1990s. Moreover, China's industrialization has led to the production of more competitive goods that are much more attractive to Kenyan and global suppliers, mainly due to their competitive lower prices (COMESA, 2009; Michael, 2006). This has led to the importation of more of these products by Kenyan suppliers. Kenya now imports essential household electric appliances, capital goods, construction materials and equipment, and machinery. This has opened up trade between China and Kenya, with traders traveling to China to purchase trade goods. Kenya has also adopted policies that have led to increased imports of I.C.T. products from China. In February 2006, the Government of Kenya made computers and computer components duty-free to strengthen the information and communications technology sector (COMESA, 2009; Michael, 2006). This has led to an increase in the imports of I.C.T. products from China. Besides, rapid growth in Kenya's telecommunications sector, in particular increased mobile users, has led to an increase in telecommunications imports. Increased imports from China, mainly manufactured goods, have led to more diversification of Kenyan imports and have contributed to Kenya's industrialization.

On the other hand, Kenya's exports to China are very low, and from the results, China is not a significant export market for Kenya. Kenya mainly exports raw goods to China, and the composition and percentage of the manufactured goods class are minimal. Kenya's exports go through little value addition, resulting in poor positioning in global value chains and uncompetitive low prices; hence low exports in the manufactured goods class (Sanghi \& Johnson, 2016). 
Moreover, poor or inadequate technological skills, high labor costs, and poor infrastructure are the primary reasons that have hindered Kenya's production of manufactured goods (Soderbom, 2001). The right technology-driven by research and development and infrastructure is vital to reduce the production cost of manufactured goods. This will lead to improved productivity in Kenya's manufacturing sector, leading to access to new markets and better positioning in Kenya's global value chains. From a policy perspective, Kenya lacks a comprehensive trade policy with China which reduces its trade orientation in the manufacturing sector. The main Kenya trade policy consists of trade agreements with the E.A.C. members, the USA, and E.U. (including UK) (Bigsten, Kimuyu, \& Söderbom, 2010). In addition, the rules of origin, especially those of China, are stricter than those of AGOA and the EU since there must be a minimum of $40 \%$ of the value addition of goods from the exporting country for export to China (Edinger, Herman, \& Jansson, 2008), which makes it very difficult for Kenya to export processed goods to China.

Overall, the data show that a large proportion of Kenya's manufactured exports end up in countries with a clear trade framework. Of the four regions analyzed, E.A.C. (Uganda and Tanzania), USA, UK and China, imports the least of them from Kenya. This could be explained by the presence of trade policy frameworks with these regions, as opposed to the absence of the same between Kenya and China. Kenya's main trade policy comprises of the trade agreements with the East African Community (E.A.C.) members, the European Union, and the United States. The trade policies with these three regions include; 1) Common External Tariff (C.E.T.) through E.A.C., which has reduced the regular applied tariff rate to $13.2 \%$ from $16.8 \%$; 2 ) Tariff and quota-free access to the European market from E.A.C. for all commodities except for temporary restrictions on sugar and rice since January 2008; 3) AGOA which increases market access to the US for qualifying sub-Saharan countries (Bigsten, Kimuyu, \& Söderbom, 2010). The E.U. is currently trading with Kenya under the Economic Partnership Agreement -E.P.A. (Omolo et al., 2016). This has led to remarkable progress in these trade relations over the last 15 years, which also explains Kenya's significant exports of both general and manufactured goods to these regions/countries. Moreover, Kenya's colonial ties with the United Kingdom partly explain more robust bilateral trade between the two countries, unlike China. Further, the East African block has been a significant market for Kenya's manufactured goods, which could be explained by Kenya's ability to produce diversified and low-cost goods while maintaining a competitive edge over its neighbors in quality and cost. Kenya is generally a leader in technical expertise, services specialization, the supply of local and imported goods to Africa, and more to East Africa.

Despite China's minimal imports from Kenya, exports of manufactured goods from Kenya to China have gradually increased since 2000. This could be explained by factors like China's zero-tariff policy on exports from the least developed countries with which it has diplomatic relations (Otenia, 2017). However, it is still difficult for Kenya's manufactured goods to penetrate the Chinese mar- 
kets. Given the strict rules of origin for exports to China and the current Chinese specialization level, it is difficult for Kenya or other developing countries to compete with China. Moreover, China produces enough for its market and is currently the world's leading exporter of manufactured goods, meaning that Kenya's exports of manufactured goods would not match China's imports. Kenya is likely to gain if it produced goods that China imports and took advantage of the improved trade links with the current trends.

\subsection{Revealed Competitive Advantage of Manufactured Goods between Kenya and China}

Over the period between 1984 and 2015, China has continuously and tremendously gained a comparative advantage in various manufactured goods while, on the other hand, Kenya has maintained a comparative disadvantage.

From the R.C.A. Below-Unity results, it is clear that Kenya has had a significant comparative disadvantage in all classes of manufactured goods and, as a result, very low competitiveness. Machinery and equipment had the lowest R.C.A., which could be explained by poor technical skills and low industrialization levels, which are not capital intensive. Kenya's manufactured products lack competitiveness in international markets; therefore, it is difficult for them to gain a market in China, which is highly integrated into global value chains due to its high specialization levels.

The lack of competitiveness of Kenya's manufactured products can be explained by various factors such as poor business environment, inadequate investment in research and development, poor infrastructure, and corruption, among others (Sanghi \& Johnson, 2016; Soderbom, 2001). This is likely to limit Kenya's comparative advantage away from the manufactured goods and more to primary ones. There is a need for Kenya to improve its manufacturing by investing more in export processing zones, providing production subsidies to local companies, enhancing technology and innovation etc. This will translate to enhanced competitiveness of manufactured goods.

On the other hand, China has generally had a mean comparative advantage in most classes of manufactured goods between 1984 and 2015. This means that most of China's manufactured goods have gained a competitive edge in international markets over time due to their quality and integration into global value chains. China's comparative advantage could be due to increased industrialization since 2000, when it shifted its growth model to a resource-based model, consisting of a comparatively high level of technical skills, increased capital intensity, a high level of specialization and technology, government support and modern infrastructure.

China has a comparative advantage in manufactured goods and exports the same to Kenya, which has a comparative disadvantage. Therefore, what China produces is different from what Kenya produces and thus complements each other. A high R.C.A. product is competitive and can be exported to low R.C.A. countries, resulting in complementarity. Accordingly, this research therefore 
suggests that China does not pose a competitive threat to Kenyan products, given that they produce different goods and that the trade relationship is complementary. Furthermore, countries with different R.C.A. profiles are likely to have high bilateral trade intensity, which is likely to explain China's high trade level with Kenya. These findings confirm the Heckscher Ohlin theory that countries export what they have in abundance and import goods that they cannot produce as effectively.

\section{Conclusion and Recommendations}

The objectives of this study were to: examine the nature of trade in manufactured goods between Kenya and China, analyze the Revealed Comparative on Manufactured Goods, and make recommendations. Per the data, Kenya generally lacks a comparative advantage in manufactured goods, as shown by the low level of R.C.A. below-unity, which translates into non-competitiveness. In contrast, China's manufactured goods are highly competitive, as indicated by the high level of R.C.A. above-unity. Thus, China produces different products from what Kenya produces, implying that Chinese exports to Kenya complement Kenya's import needs. Furthermore, the nature of trade is characterized by high imports from China, mostly manufactured goods, and shallow levels of exports from Kenya to China. China is currently Kenya's leading source of manufacturing and general imports after overtaking India in 2014. Generally, a large proportion of Kenya's manufactured exports end up in countries with which it has a clear trade framework, such as the E.A.C., the USA, and the E.U. (including the $\mathrm{UK})$.

The potential for future growth in trade in manufactured goods from Kenya to China is weak, based on existing economic specialization. Kenya should focus on products with a comparative advantage, enabling it to gain a competitive edge and more trade orientation on the Chinese market. However, Kenya should also aim to create its comparative advantages; it could learn lessons from China on creating and improving its comparative advantage. The comparative disadvantage of most Kenyans is a reason enough to force Kenya to explore ways to strengthen its manufacturing sector. Countries change their specialization patterns with changes in factor abundances, such as capital deepening for the production of capital-intensive products. As the two countries strive to bridge the bilateral trade gap, Kenya needs to add value to its exports. China offers opportunities that Kenya should take advantage of; opportunities to develop the infrastructure needed for the desired competitiveness, technology transfer, an increase in the commodity market, and entrepreneurial skills development. This could be done by sharing experiences between Kenya and China, particularly the teachings emanating from China's development process. Global value chains (G.V.C.s) are crucial to today's international economy-the growing importance of I.C.T. would empower Kenya to join many value chains without necessarily developing the production process to its fullest. 
Clearly, a well-articulated trade policy would aid in promoting trade and, in particular, manufacturing goods between Kenya and China, as the lack of a comprehensive trade policy between Kenya and China seems to reduce its trade orientation in the manufacturing sector. This includes a policy to protect Kenya's exports to China and, more importantly, a possible preferential treatment for Kenya. Getting the right trade policy means harmonizing incentives for firms to be innovative, improve capacity, invest in research and development, and improve the technology. A clear and comprehensive trade policy between China and Kenya would positively impact Kenya's manufactured exports, as seen from trade between Kenya and other partners where there is a well-articulated trade policy.

It is also vital that Kenya explores opportunities from other markets, apart from its traditional trading partners, to increase its export base, particularly in manufactured goods. China is not one of Kenya's traditional export partners, and, as a result, Kenya should make sufficient efforts to diversify its exports and penetrate the Chinese market because, as it stands, China offers Kenya a large potential market. Given China's growing trade presence in Kenya, producers should be more concerned with identifying new or more opportunities in other sectors other than manufacturing, as China's strength in manufactured goods continues to grow, which may be very difficult for Kenya to counteract. Rebalancing China into a consumer-driven economy means increasing imports into Chinese markets for consumption. Kenya could take advantage of this and explore the products and probably the services it could export to China when this happens. These sectors could include the horticultural, tourism, and services sectors, among others. Although there is a trade balance between the two trading partners, China has made an effort to put measures to address this, as seen from its preferential tariffs on L.D.C. Africa. The list of items eligible for preferential tariffs from China offers a unique opportunity to develop commodity value chains in Kenya. Unfortunately, Kenya has not done enough to raise awareness among its people about the business opportunities available in China, and it is high time the government put more effort into this.

For Kenya to accelerate its industrialization quest and be able to eye other markets with competitive manufactured goods, it should aim to create a favorable business operating environment that will see both foreign and local investors set shops locally and be part of the journey. Unfavorable business environment through regulations, taxation regime, energy cost, and other factors remain significant obstacles to achieving industrialization targets, and hence locally manufactured goods remain uncompetitive in the global markets. Therefore, Kenya needs to support more FDI in manufacturing, increase the number of export processing zones, offer production subsidies, promote research and development, lower transport and energy costs, improve labor productivity and infrastructure, reduce the regulatory burden of trade for increased exports, and by extension the share of manufacturing in GDP, which is expected to be $20 \%$ under the 2030 vision. 
Finally, the study was limited in that it used aggregate data (Standard International Trade Classification-Class One Goods), limiting the range of issues that could be addressed in relation to specific industries/firms. Thus, the conclusion of this research is derived from aggregate trade data and can only be applied in general. Although this study concluded that trade between China and Kenya is mainly complementary, competition may exist for specific products or groups of products. A more detailed analysis of trade at the product and firm-level would be required to further explore complementarity and/or competition.

\section{Conflicts of Interest}

The author declares no conflicts of interest regarding the publication of this paper.

\section{References}

Abdirahman, S. (2020). The Economic Impact of Chinas Relations with Africa: Case Study of Kenya. Nairobi: University of Nairobi.

Adem, S. (2016). China's Diplomacy in Eastern and Southern Africa. London: Routledge. https://doi.org/10.4324/9781315571683

Ademola, O. T., Bankole, A.-S., \& Adewuyi, A. O. (2016). China-Africa Trade Relations: Insights from AERC Scoping Studies. In S. Henson, \& O. F. Yap (Eds.), The Power of the Chinese Dragon (pp. 69-97). London: Palgrave Macmillan.

https://doi.org/10.1007/978-1-137-57449-7 4

Bigsten, A., Kimuyu, P., \& Söderbom, M. (2010). Chapter 10: The Manufacturing Sector. In C. Adam, P. Collier, \& N. Ndung'u (Eds.), Kenya: Policies for Prosperity (pp. 1-25). Oxford: Oxford University Press and Central Bank of Kenya.

Chege, J., Ngui, D., \& Kimuyu, P. (2014). Scoping Paper on Kenyan Manufacturing. Helsinki: World Institute for Development Economics Research.

Chege, M. (2008) Economic Relations between Kenya and China, 1963-2007. The Guardian (London).

Chen, G., Geiger, M., \& Fu, M. (2015). Manufacturing FDI in Sub-Saharan Africa. Washington DC: World Bank.

Common Market for Eastern and Southern Africa (COMESA) (2009). Common Market for Eastern and Southern Africa (COMESA) Tax Guide 2009. Lusaka: COMESA Regional Investment Agency.

Deloitte (2016). Kenya Economic Outlook 2016: The Story behind the Numbers. London: Deloitte.

Edinger, H., Herman, H., \& Jansson, J. (2008). New Impulses from the South: China's Engagement of Africa: Mimeo. Stellenbosch: Centre for Chinese Studies.

Farole, T. (2011). Special Economic Zones in Africa: Comparing Performance and Learning from Global Experiences. Washington DC: World Bank.

Foster, V., Butterfield, W., Chen, C., \& Pushak, N. (2008). Building Bridges: China's Growing Role as Infrastructure Financier for Sub-Saharan Africa. Washington DC: World Bank.

Gertz, G. (2008). Kenya's Trade Liberalization of the 1980s and 1990s: Policies, Impacts, and Implications. Background Paper on the Impact of Doha Round on Kenya.

Githaiga, N. M. (2021). The Successes and Challenges of Kenya's Mombasa-Nairobi Stan- 
dard Gauge Railway Transport Operations: A Special Reference to the Users. Research in World Economy. (In Press)

Githaiga, N. M., \& Bing, W. (2019). Belt and Road Initiative in Africa: The Impact of Standard Gauge Railway in Kenya. China Report, 55, 219-240. https://doi.org/10.1177\%2F0009445519853697

Githaiga, N. M., Burimaso, A., Bing, W., \& Ahmed, S. M. (2019). The Belt and Road Initiative: Opportunities and Risks for Africa's Connectivity. China Quarterly of International Strategic Studies, 5, 117-141. https://doi.org/10.1142/S2377740019500064

Government of Kenya (GOK) (2015). Nairobi: Kenya National Bureau of Statistics.

Guerrero, D. G., Manji, F., \& Manji, F. M. (2008). China's New Role in Africa and the South: A Search for a New Perspective. Fahamu/Pambazuka.

KAM (2007). Position Paper on Counterfeits', Presented to the Finance, Trade and Planning Parliamentary Committee. Nairobi: Kenya Association of Manufacturers Standards and Regulatory Committee-KAM.

Kaplinsky, R., McCormick, D., \& Morris, M. (2010). China and Sub Saharan Africa: Impacts and Challenges of a Growing Relationship. Nairobi: University of Nairobi.

Krugman, P. R., \& Obstfeld, M. (2009). International Economics: Theory and Policy. London: Pearson Education.

Leseure, M., Hurreeram, D., \& Bennett, D. (2009). Playing Catch-up with China: Challenges and Strategies for Smaller Developing Countries. Technology Analysis \& Strategic Management, 21, 617-637. https://doi.org/10.1080/09537320902969158

Li, W., \& Li, C. (2020). The Empirical Study on Potential of Bilateral Trade between China and Kenya in the Context "The Belt and Road". Theoretical Economics Letters, 10, 119-130. https://doi.org/10.4236/tel.2020.101008

Michael, C. (2006). Economic Relations between Kenya and China, 1963-2007. Washington DC: Center for Strategic and International Studies.

Møller, K. (2012). The Role Kenya's Civil Society Can Play in Ensuring a Mutually Beneficial Sino-Kenya Engagement. POLIS Journal, 7, 242-282.

Nguku, G. W. (2013). External Environmental Factors Influencing China-Kenya Trade: A Case Study of the Ministry of Foreign Affairs and International Trade and Chinese Embassy in Kenya. Nairobi: University of Nairobi.

Odhiambo, P., \& Malot, K. (2018) Trade Imbalance between Kenya and China Nairobi. Nairobi: Kenya Institute for Public Policy Research and Analysis.

Omolo, M., Jairo, S., \& Wanja, R. (2016). Comparative Study of Kenya, US, EU and China Trade and Investment Relations. Nairobi: Institute of Economic Affairs.

Onjala, J. (2008). A Scoping Study on China-Africa Economic Relations: The Case of Kenya.

Onjala, J. (2010). The Impact of China-Africa Trade Relations: The Case of Kenya.

Onjala, J. (2017). China's Transport Infrastructure Support in Eastern Africa: Security Implications for the Indian Ocean Rim. Issues in China-Africa Relations, 151.

Otenia, T. (2017). Chinese Zero-Tariff Treatment for Least Developed Countries: China's Soft-Power in Action in Africa International and Public Affairs, 1, 39-46.

Palley, T. I. (2008). Institutionalism and New Trade Theory: Rethinking Comparative Advantage and Trade Policy. Journal of Economic Issues, 42, 195-208.

https://doi.org/10.1080/00213624.2008.11507121

Patroba, H. (2012). China in Kenya: Addressing Counterfeit Goods and Construction Sector Imbalances. Johannesburg: South African Institute of International Affairs. 
Sanghi, A., \& Johnson, D. (2016) Deal or No Deal Strictly Business for China in Kenya? No. 7614, Washington DC: World Bank Group. https://doi.org/10.1596/1813-9450-7614

Siringi, E. (2018). Kenya-China Trade Relations: A Nexus of “Trade not Aid” Investment Opportunities for Sustainable Development. Journal of Economics and Development Studies, 6, 24-35. https://doi.org/10.15640/jeds.v6n2a4

Soderbom, M. (2001). Constraints and Opportunities in Kenyan Manufacturing: Report on the Kenyan Manufacturing Enterprise Survey 2000. University of Oxford.

Suresh, K. G., \& Neeraj, A. (2014). Determinants of India's Manufactured Exports to South and North: A Gravity Model Analysis. International Journal of Economics and Financial Issues, 4, 144-151.

Titiloye Ademola, O., Bankole, A. S., \& Mefalopulos, P. (2009). China-Africa Trade Relations: Insights from AERC Scoping Studies. European Journal of Development Research, 21, 485-505. https://doi.org/10.1057/ejdr.2009.28

UN Comtrade Database (2015). http://comtrade.un.org/

United Nations Conference on Trade and Development (2008). Trade and Development Report. New York and Geneva: United Nations Conference on Trade and Development.

United Nations Economic Commission for Africa (UNECA) (2015). Economic Report on Africa 2015: Industrializing through Trade. Addis Ababa: United Nations Economic Commission for Africa.

Warui, M. G. (2010). The Effect of China-Kenya Economic Ties on Social and Economic Development in Kenya. Master's Thesis, Nairobi: University of Nairobi.

World Bank Group (2015). Kenya Leather Industry: Diagnosis, Strategy, and Action Plan. Washington DC: World Bank. 